\title{
Is traditional music really dying?
}

\author{
Agonia, directed by Tomasz Knittel, \\ screenplay by Adam Strug, TVP 2020
}

DOI: 10.12775/LL.1.2021.009 | CC BY-ND 3.0 PL

The film is about the agony of Polish traditional music and its natural world. At the beginning, it should be noted that there already exists a number of film texts that have a more or less specific relationship to this topic. It can be assumed that this motif in Polish cinematography originated with a documentary from over 60 years ago about the ethnomusicologists Jadwiga and Marian Sobieski, as well as traditional musicians and singers (Grabowski 1958). These are only a dozen or so snapshots of field recordings, with concise commentary by Julia Hartwig, but the title itself is meaningful in the context of the Agony in question. Namely, it reads Melodie, które nie zgina (Melodies that will not be lost); thanks to the recordings - as the narrator says - "they will return, like migratory birds return to their family nest".

There are certainly about forty films on this topic that were made later - both in the People's Republic of Poland (see Łukomski 1987) and after 1989 (no list here). I have worked on a dozen or so as a screenwriter ${ }^{1}$. They were usually portraits (biographical films) of specific musicians and singers and their work - which at that time constituted a new quality of television documentary, because they concerned artists in crudo, non-stylized. The subject of the end appeared there as one of the threads, rather indirectly, between the lines. There were also purely artistic pictures, such as the Dziewce z ciortem (Girl with a Devil) by Piotr Szulkin (1975), but rarely. Agonia is the first film that deals with this issue as the main topic and, apart from the undeniable qualities of good reportage, which are sometimes stirring, it has a journalistic perspective which inspires a discussion, and maybe even a dispute, due to the fact that just as it asks many questions, it also provokes asking Adam

1 The series Klechdy polskie (Polish Legends) directed by Jarosław Ostaszkiewicz and the series Centrum czyli pogranicze (Center therefore Borderland ) directed by Dariusz Gajewski; both series produced for $\mathrm{TVP}_{2}$. 
Strug - its narrator, screenwriter and the main character - some questions. This is the result of the fact that the film is strongly influenced by his personal vision.

In Agonia, just as in the above-mentioned films, we also have heroes of rural musical traditions (Kurpie, Radomskie or Podhale). Although they appear on screen for a short time, it must be admitted that they are intriguing - each of them plays or sings a piece, and comments on it. They manage to mark their individuality in a few lines of dialogue, and at the same time they are intentionally treated in the journalistic narrative as representatives of a larger community. There are also two (or even three, counting Krzysztof Trebunia-Tutka's childhood students) generations of young people from cities (and not only from cities), who in turn represent a wider phenomenon called the dance house movement. In other words, this concerns the revival movement, and, in some cases (such as Podhale), the continuity of traditional music. The "young" ones, although their habitus is different, their cultural span much broader and their identity less homogeneous, participate in this tradition. They make a nest in it (after all, the essence of the term "tradition" is transmission). These two groups are linked by the figure of Andrzej Bieńkowski, an active painter, documenter of traditional music, its watchful observer and commentator with a sociological and ethnographic temperament. The set of the film is therefore densely populated and gives the impression of one "new village" which could be understood in many ways.

Although, of course, I understand the rules governing the production of such films - especially when it comes to the time frame (the film is an hour long) and care for the cohesion of the structure - I must mention the aspects that I miss in this picture, if only to not forget them in post-film discussions. The representatives of two regions are absent here: Greater Poland (continuity slightly different than in the Carpathians) and Lower Silesia (a specific repatriate, migration and cultural mosaic, in addition located on former German lands). There is also a shortage of academics, both in the older generation (e.g. Piotr Dahlig - a pioneer of a new kind of field documentation, with a very broad, free of presentism outlook, who formulates valuable reflections) as well as among the young generation, which includes many musicians, a fact which distinguishes them from previous arm-chair researchers. I am also troubled by the fact that the problem of regional or micro-regional song and dance groups or other similar initiatives was ignored in the film discussion. The provenance of such groups is much more complex than in the case of "Mazowsze" and "Śląsk" . Additionally, in the case of such large ensembles, it should be added that their tradition is longer than that introduced according to communist rules and aesthetics of socialist realism.

I can find one explanation for these shortcomings: the film was intended to reflect the counterculture and quite elitist nature of the revival movement, creating an alternative option, however niche, but significant in the face of organized forms, which, even if they were largely grass-roots, were based on the system of state institutions. Adam Strug's intention was probably to draw a clear distinction be-

2 "Mazowsze" and "Śląsk" are the names of state-owned song and dance ensembles established during the communist era, employing dozens of dancers, musicians and technical workers who specialize in performing arrangements of folk music. 
tween two types of traditional music. The first of them is the more archaic, in crudo, which was an act of communication that could "say more than all the words" (Krzysztof Trebunia-Tutka) $^{3}$ - a corporeal and spiritual act, and at the same time causative (social) and life-giving (in Stanisława Galica-Górkiewicz's words, "there is good in music"). The second one is newer, less spiritual, perhaps cultivated only for pleasure, for a smaller or larger stage or as a reminder (but even as a souvenir as Krzysztof Trebunia-Tutka states - it should be "full of style"). Importantly, each of these varieties in the ontological paradigm of traditional folk music has a different and specific impact on the aesthetics and performance style. At the same time, it is difficult to avoid the impression that this typology is evaluative and originates outside the culture to which it refers, because the carriers themselves often have a different opinion on this subject. I omit the fact that every person of a certain age longs for youth, and in the film we are dealing with masters representing the older and oldest generations of rural musicians.

In his narrative, Adam Strug often refers to the past in its non-dynamic form. He describes the musical tradition as a "commune (also known as tribal), noble and church" tripod, speaks of "19th century repertoire ranges", "free Kurpie peasants, unfamiliar with serfdom, guardians of the royal forest", and about the "isolation that caused, that the oldest Masovian dialect and music has survived there". And he sighs: "If we had lived a hundred years ago ...". I see a romantic print in it, which Strug emphasizes probably in order to enhance the features of a culture in agony. In his story, the past freezes like an insect in amber, and the contemporary reality, within which the remnants of the old musical legacy are transmitted, cannot be defined precisely, while the future remains a mystery. But isn't that fascinating in itself?

In a sense, traditional culture ends and ceases to be alive in the old way, when it is no longer a secret bound by internal codes and various taboos that co-create the bloodstream of the community; the continuity of their functioning is largely ensured by oral communication, but also the underappreciated body language (Connerton 1989). In order to master the craft, i.e. the individual secret of a given master, remaining in the stream of living tradition, it was sometimes necessary to "steal" it, or at least show some cunning. When the holders of tradition (folklore) start talking about it, they probably do not practice it anymore. Antoni Kroh (1999) writes about it suggestively. Folklore which ceases to be relevant because the world that enables its existence changes radically becomes a story about folklore (Sulima 200o), and people who practiced it before turn into certified guardians of the story. Today, city youth can take over traditional music so smoothly and relatively seamlessly just because the culture that brought it into the world is dying out. This is the whole paradox and tragedy of this situation. People who leave take some of their culture with them. Let us give them the right to do so. And their musical language can be learned. It will never be the same, but who said it had to be. This traditional language can be implemented in new times as something of one's own, something personal, a part of one's own identity, of course getting to know it well, but also taking advantage of the creative freedom specific in today's times. 
This freedom does not have to be a fault, but can also be an added value. The artistic quality is decisive here, as well as the personal truth and fidelity to one's own, more and more often mosaic or even kaleidoscopic, identity.

There are a lot of emotions in the movie that begins and ends with a funeral. The most touching moment is the oberek played by mourners over the grave of the Radom harmonist Tadeusz Lipiec. But almost every scene conveys strong emotions through statements, music and body language. Despite the journalistic narrative, the film is not an over-intellectualized essay and, in the end, it deals primarily with feelings, which, after all, constitute the raison d'être and the power of music, showing them in verbal, performative, sound way. In one of the movie scenes there is a significant exchange of sentences: „You have twenty good bands, so what more do you expect?” - says Andrzej Bieńkowski, to which Adam Strug replies: "I expect context". One can therefore ask whether in the times of "village without a village" these feelings are not enough for the context that Strug expects. At least, this is how I perceive the few voices that can be heard at the end of the picture (by Andrzej Bieńkowski, Stanisława Galica-Górkiewicz, Ewa Grochowska) as a kind of postscript and a counterpoint to the gloomy tone that floats like smoke through the hut during most of the film. Because if feelings are not the issue here then I do not quite understand what Strug means when he talks about the context. I only have an intuition that in some sense metaphysics may be involved. Anyway, I do not know why this context has to suddenly "happen" while "it is still happening"? Anthropological works or artistic statements often say more about the author than he would like to say about himself. As it seems, this is also the case here, because this film is, in a sense, a portrait of Adam Strug.

But can the eponymous "agony" not be read also through the etymological prism as agon, i.e. a competition as old as the world? In this case, it would be a rivalry between Thanatos and Eros. After all, in the ancient culture, to which the narrator of the film fondly refers, this motif was strongly present. The old ones are leaving, their loved ones are lamenting, but all the more they want to reaffirm life. And nowadays the grandfather is lying on the stretchers, while in the next room the children are playing, the young people are having fun (they would dance if someone played music), sometimes they are conceiving a child, and most importantly they eat and drink, because feasting overcomes death. And then they go to a football match or to the seaside to Croatia. If we look at this agonist of death and life, tradition and modernity from a historiosophic perspective, the meaning of the eponymous "agony" becomes less pronounced, more relative, and does not give any reason for erasure of the presence of traditional music so easily.

Finally, Agonia provokes reflection and I focused on it, but it also has (which should be emphasized, because it is not so obvious here) purely cinematic qualities - tasteful shots that give breath, direction that is clear, and at the same time imposes right rhythm, clarity and dramatic coherence of the narrative, as well as the associated original editing. Both the director Tomasz Knittel and the editor Kuba Pietrzak (who is also the filmmaker) are well-versed in the subject, which is noticeable. The soundtrack is also worth noting; it could easily be broadcast as a radio report. Thus, Agonia is a production worth recommending. Despite the fact that it cuts some curves and avoids others, in many respects it is a fresh text in the 
filmography of folk music, which could not have been created 20 years ago. This does not mean, however, that it will not become outdated surprisingly quickly for a few reasons which could not only be the subject of another article but also another movie entirely.

\section{REFERENCES}

Connerton, P. (1989). How Societies Remember. Cambridge: University Press.

Grabowski, S. (director), Sobiescy, J. i M. (screenplay) (1958). Melodie, które nie zagina [documentary]. Polska: Wytwórnia Filmów Oświatowych.

Kroh, A. (1999). Sklep potrzeb kulturalnych. Warszawa: Prószyński i S-ka.

Łukomski, M. (1987). Polski film etnograficzny. Warszawa: Ludowa Spółdzielnia Wydawnicza.

Sulima, R. (2000). Antropologia codzienności. Kraków: Wydawnictwo Uniwersytetu Jagiellońskiego.

Szulkin, P. (director) (1975). Dziewcę $z$ ciortem [short film]. Polska: Wytwórnia Filmów Oświatowych. 